\title{
AFGHAN VILLAGE
}

\author{
AN ETHNIC GRAY ZONE
}

\author{
by LOUIS DUPREE
}

Attributes of the Peasant-Tribal Society 1. Nonliteracy and etholinguistic diversity. In Afghanistan, over 90 percent of the population is illiterate. Linguistic diversity remains a divisive factor and in the Aq Kupruk area alone, two major language families are represented.

2. Ecological time-energy relationship. Most of the people of Aq Kupruk spend the major part of their time engaged in basic food production, either agriculture, herding, or, more commonly, a combination of the two.

3. Limited mobility. Peasant-tribal societies limit social, economic, political, and geographic mobility, usually to help insure group survival at the expense of individual choice.

4. No adolescence for children. The individual lives in a group-oriented, uniinstitutional, rural society: the extended family and other kin units. Child socialization takes place inside the family. The child becomes an adult almost overnight, with a full range of social, economic, and political responsibilities. About the time children in developed societies are preparing for their roles, the Aq Kupruk child begins to live $h$ is. There is no time of learning away from the family; the family is the way of life.

5. Kinship replaces government. Few governments in the Third World can replace the delicate network of reciprocal, social, economic, and political rights and obligations which function in the various kin-units at the regional and tribal level. Rights and obligations are tightly defined and include everything from the right to name a child to social welfare and warfare. Contacts with outside-taxes, military conscription, forced labor, women for the harems of the powerful and wealthy-are usually viewed negatively.
Aq Kupruk is a village-town of the neolithic yesterday and the transistorized today. It is like a long time tunnel, encompassing thousands of years. It combines a sense of unending time with limited space and the symbiosis of incipient town life, agricultural cycles, and nomadic existence. The record of the emiergence of proto-urban culture at Aq Kupruk can be read in the village and its valley: animal and plant domestication, grain growing, surplus accumulations, specialization in the bazaar, and the contemporary efforts at national integration of the local entity. If stones are the stuff of history, a town like Aq Kupruk is one of the foundation stones of continuing human development.

\section{The Geographical Setting}

The valley of Aq Kupruk sits south of the Turkestan plains in the northern foothills of Afghanistan at an altitude of about 750 meters above sea level.The foothills are north of the Hindu Kush watershed, a broad zone of mountainous plateau stretching from about $70^{\circ}$ East to the Iranian-Afghan border. A series of north-south valleys formed by various rivers flowing out of the Hindu Kush dominates the topography. Passes separate the various valleys, whose broader floodplains support the bulk of the local population.

Low, bare, limestone, shale, and sandstone mountains with rounded summits surround most populated valleys. Soils in the upper reaches are usually thin and stony. In the lower foothills, however, including $\mathrm{Aq}$ Kupruk, rich loess deposits, blown for millennia off the Central Asian steppes, blanket the region. Seasonally, these hills are covered with flowering, grassy meadows over which the flocks of both sedentary and seminomadic peoples graze. In addition, farmers grow unirrigated crops, including wheat, barley, and melons, on the hillsides, leaving fields fallow periodically to renew their fertility.

Rich deposits of silts, clays, and redeposited loess can be found where the river valleys broaden, especially as one approaches the Turkestan plains, and intensive, irrigated farming takes place. Most of the people in the region still depend on upland wheat for subsistence, however, and droughts can cause local havoc in zones of relative inaccessibility.

Generally speaking. Aq Kupruk's climate is characterized by warm, dry summers and cold winters with heavy snowfall, especially in the higher mountains. Maximum rainfall occurs in February, March, and April, and melting snows swell the rivers and streams during the spring. Sometimes lorries cannot reach the town of $\mathrm{Aq}$ Kupruk for days at 3 time.
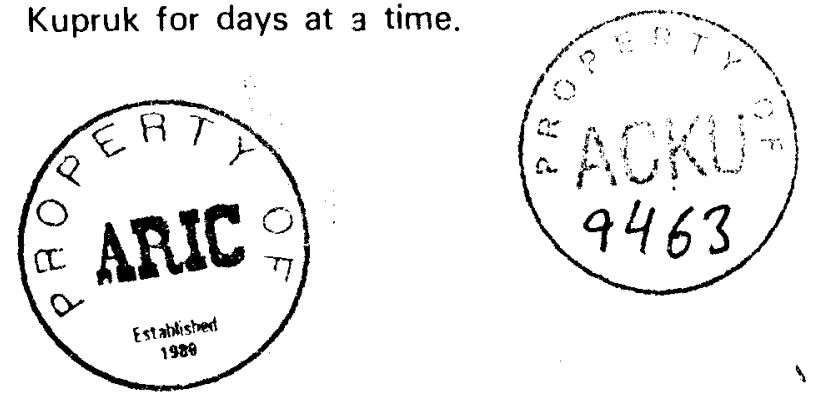
THE AFGHANISTAN SERIES FILMS/ESSAYS

1. An Afghan Village: $44 \mathrm{~min}$.

2. Naim and Jabar: $50 \mathrm{~min}$.

3. Wheat Cycle: 16 min.

4. Afghan Women: $17 \mathrm{~min}$.

5. Afghan Nomads: The Maldar: $21 \mathrm{~min}$.

\section{The Author:}

LOUIS DUPREE, who joined the AUFS in 1959, is an anthropologist who has specialized in the Indo-European language areas of the Middle East and Central Asia. Dr. Dupree first visited Afghanistan in 1949 and again in 1950-51 for the American Museum of the University of Pennsylvania. After receiving his Ph.D. degree from Harvard in 1955, Dr. Dupree joined the faculty of the Air University where, concurrent with his Field Staff affiliation, he is an Adjunct Professor. In 1973-74, he was a Fellow, American Council of Learned Societies at Kings College, Cambridge. His published works include Afghanistan, a new edition of G. Robertson's Kafirs of the Hindu Kush, and Afghanistan in the Seventies, eleven monographs and numerous articles and reveiws in such varied publications as American Anthropologist, The Nation, The Economist, Evergreen Review, and the Middle East Journal. He is based in Kabul to observe developments in Afghanistan, Pakistan, Bangladesh, and Soviet Central Asia.

Location: Balkh Province, an area inhabited by Tajik and other Central Asian peoples. 2200 feet altitude; wheat growing and pastoral economy. The town of Aq Kupruk is approximately 320 miles (14 road hours) northwest of Kabul.

Film/Essay Precis: A collage of daily life in Aq Kupruk builds from the single voice that calls the townspeople to prayer, the brisk exchange of the bazaar, communal labor in the fields, and the uninhibited sports and entertainment of rural Afghans.

Theme: Rural Society. The films and essays in this series explore concepts of development, modernization, environmental equilibrium, and especially change, identifying change agents, and analyzing barriers and stimulants to change. Film Link $\begin{aligned} & \text { FilM } \\ & \text { LiNK }\end{aligned}$ film.
film symbol in the essays indicates direct relationship to a scene or event in the

Film Dialogue Denotes direct quotation from the sound track and indicates specific relationship between the film and essay.

Acknowledgement: The AUFS wishes to express it gratitude to the people of Aq Kupruk for their hospitality and cooperation.

I wish to thank my wife, Nancy Hatch Dupree, for her unflagging assistance in the field and in the preparation of all the film essays.

The Afghan Bureau of Consulting Architects and Engineers (ABAD) and its President, N.A. Saberi, were most helpful with maps and drawings, as was Douglas Waugh, the cartographer. I also wish to thank Sultan Hamid for his advice and skill in the printing of many of the photographs.

NSF/AUFS Credit: $\odot$ "Copyright 1976. All rights to materials reserved by others, the Publisher and the Copyright owner hereby grant permission without charge to domestic persons of the United States and Canada for use of this Work and related materials in the English language in the United States and Canada after 1983. For conditions of use and permission to use the Work or any part thereof for foreign publications or publications in other than the English language, apply to the Copyright owner or publisher. Publication pursuant to any permission shall contain an acknowledgment of this copyright and the following statement:

All of the materials incorporated in this Work were developed with the financial support of National Science Foundation Grant SED 76-05281. However, any opinions, findings, conclusions, or recommendations expressed herein are those of the author(s) and do not necessarily reflect the views of the Foundation." 
Afghanistan

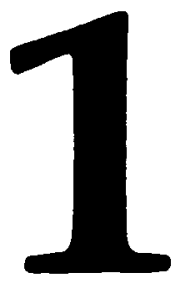

Rural Society
Film Essay

Faces of Change AN AFGHAN VILLAGE

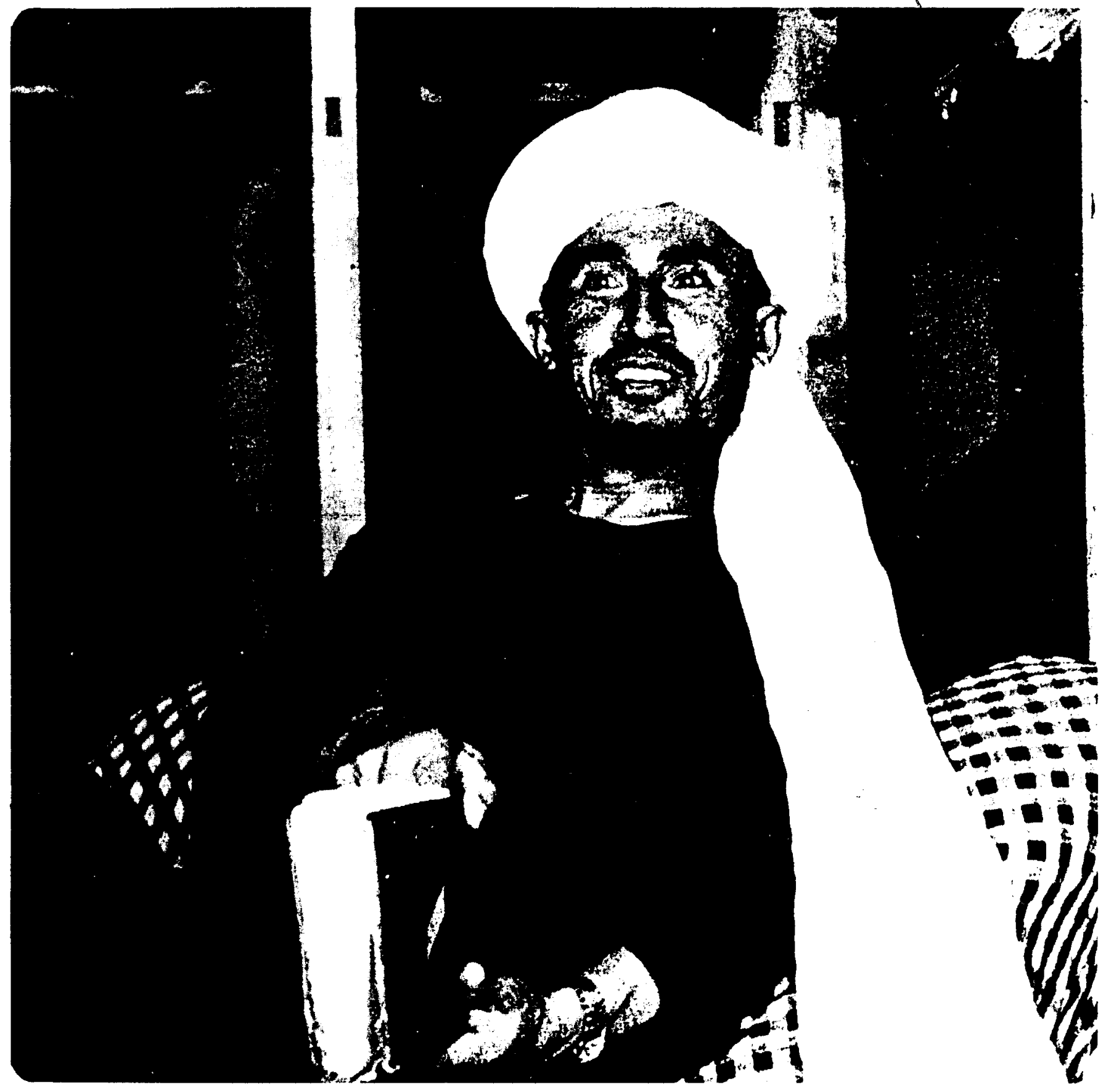




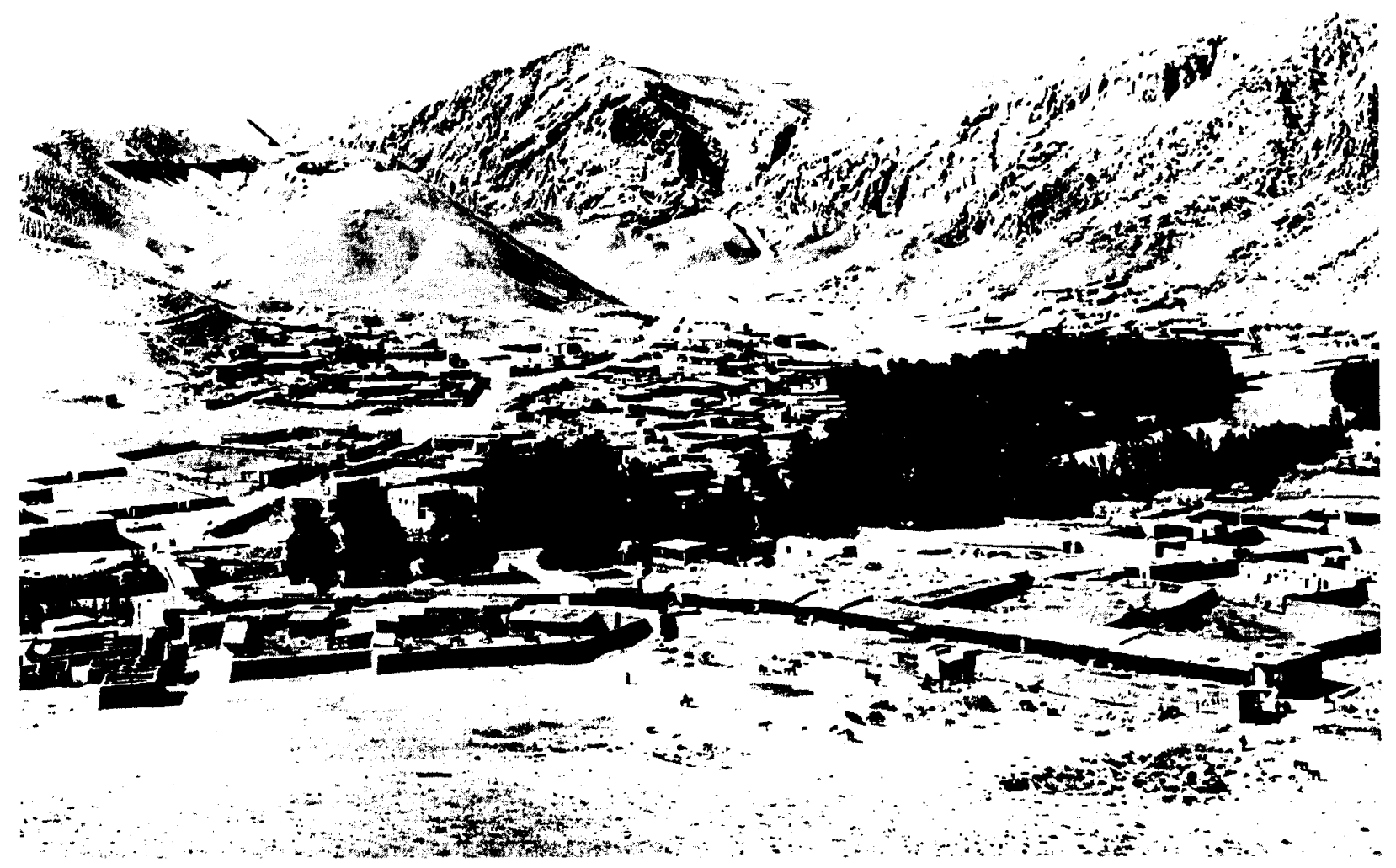

The village of Aq Kupruk.

"People have lived in Aq Kupruk since time began." According to an old Tajik folkteller, it literally began with Eden. Regional pride leads the people to believe that Allah would not have neglected $A q$ Kupruk in the original act of creation. In fact, man did come to $A q$ Kupruk at least 20,000 years ago - and probably earlier. A series of defaced Buddhist paintings on the roof of a prehistoric rock shelter reminds us that $\mathrm{Aq}$ Kupruk was on one of the main routes to India leading off the major Silk Route from Cathay to the Classical Mediterranean World. Politically, the period was Kushan; culturally, Buddhist. The precise date when Islam came to the valley of $\mathrm{Aq}$ Kupruk is unknown, but probably it was during the cultural revival introduced by the Samanids (819-1005 A.D.) from their capital in Bokhara.

\section{People and Culture}

Two basic ethnolinguistic groups reside in the town of $\mathrm{Aq}$ Kupruk, Tajik and Uzbak. Little differentiates the cultural patterns of the two save mother tongue. The Tajik speak Tajiki, a Persian (called Farsi in Iran; Dari in Afghanistan) dialect of the IndoEuropean language family; Indo-Iranian sub-family. The Uzbak speak Uzbaki, a Kipchak (Turkic) dialect of the Uralic-Altaic language family. Although Dari is the lingua franca for much of Afghanistan, a hybrid Tajiki-Uzbaki subdialect appears to be emerging in the Aq Kupruk area. 
Generations of miscegenation cause both Tajik and Uzbak to exhibit Mongoloid physical features. The Tajik, however, are basically Caucasoid. There is disagreement as to which group arrived first in Aq Kupruk but consensus gives the Tajik priority. Among the Tajik, two groups consider themselves to be descended from the Arabs who first arrived in Central Asia in the seventh century A.D. The Term "Tajik" is probably from an Old Persian word for Arab, Taj or Taz. " In time, the term came to refer to all Muslims in Central Asia, and finally to distinguish Persian speakers from Turkic speakers.

The Saadat (plural for Sayyid) consider themselves to be descendants of the Prophet Mohammad, through his daughter, Fatima, and his cousin and son-in-law, Ali. The Khoja (or Khwaja), according to local tradition, are descendants of Abu Bakr, First Caliph in Mecca from 632-634 A.D. after the death of the Prophet Mohammad. Possibly some of the Saadat in Aq Kupruk are truly Sayyid, but none speaks Arabic and all look at least moderately Mongoloid. They are probably Tajik whose forefathers married into Saadat groups and adopted the individual title "Sayvid" to enhance their prestige. When asked to vshich tribe or ethnic group (qaum) they belong, most reply "Tajik." Only the more affluent consistently use the honorific "Sayyid." More important, however, the people of Aq Kupruk and the majority of the Saadat (there are some doubters among the recently literate) believe the Saadat to be the true Descendants of the Prophet, and often ask the wealthiest, politically powerful Saadat to mediate disputes; most of the affluent people in Aq Kupruk are Saadat.

The Khoja in Aq Kupruk present an even more complex problem. Like the Saadat, the Khoja are found in most of the Muslim world. Most Khoja outside Afghanistan are the followers of the Ismailiya Shia leader, Agha Khan IV, but all the Aq Kupruk Khoja profess to be Hanafi Sunni, the school of Islamic law which predominates in Aq Kupruk. In 1962, however, one family of Khoja did claim to be Ismailiya. Therefore, either the Khoja of Aq Kupruk are Tajik passing as the descendants of the Arab Caliph Abu Bakr, or Ismailiya Shia practicing taqiya, a most practical custom by which Shia claim to be Sunni in order to protect lives and property or, as in Kabul, retain government jobs in a Sunni-dominant society. Overall, the Tajik are superior numerically and also dominate the power structure.

The Tajik and Uzbak in Aq Kupruk refer to all Pushtun as Afghan, in spite of campaigns by present and past governments to convince all ethnolinguistic groups to consider themselves Afghans first. All non-Pushtun groups refer to themselves by their own designations (Tajik, Uzbak, Hazara, Turkoman, Baluch, etc.) - but they always call the Pushtun "Afghan." Tajik, however, often refer to themselves after their valleys of origin [Panjsheri, Andarabi, etc. ; the Hazara, by old tribal names, such as Jigatu, Jaghori, Dai Zangi, etc.).**
*Tazi in modern Afghanistan refers to the Afghan hound, which the Afghans do not consider dogs. Muslims, in general, consider dogs unclean, and mistreat them, but not the tazi.

\section{Chart 1}

Households in Aq Kupruk: 1959-1972*

\begin{tabular}{|c|c|c|}
\hline Tajik & 100 & 80 \\
\hline Saadat & 100 & 90 \\
\hline Khoja & 50 & 40 \\
\hline Uzbak & 50 & 40 \\
\hline Pushtun & 1 & 1 \\
\hline & 301 & 251 \\
\hline
\end{tabular}

*The average number of persons per household is about seven. Unless prompted, the people never give population figures in numbers, but rather the number of househoids (khanah). When asked about individuals, they respond with the number of males past puberty. Only reluctantly will they even mention the female population. Also, the Uzbak minority had a tendency to overestimate its actual size at least two times.

\footnotetext{
**A single family of Safi Pushtun lived in Aq Kupruk for 20 years. They had been moved forcibly from the Kunar River area (near Jalalabad in east Afghanistan) to Aq Kupruk in 1949 after an unsuccessful revolt against the government. The two Safi adult males had married Tajik women, and in Aq Kupruk usually referred to themselves as Tajik, but always as Pushtun or Afghan outside the valley. The Pushtun household left Aq Kupruk in 1969, and, along with several Khoja and Uzbak households, moved to Sholgara.
} 
Chart 2

Tajik Subgroup Households in Aq Kupruk: 1972

Tajik Saadat Khoja
Proper

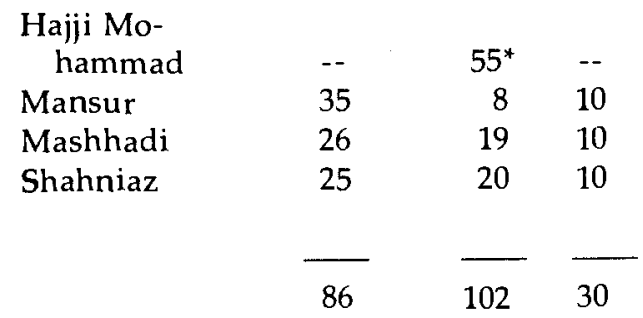

*The Hajji Mohammad group may have the only reasonable claim to call themselves Saadat.
Four Tajik subgroups exist in Aq Kupruk, and three of the groups contain Tajik proper, Saadat, and Khoja (Chart 2). All four names represent four brothers, who were the founders of the units named after them. But no one in Aq Kupruk can trace his ancestry beyond his great-grandfather, and some are even hazy about that. The ethnic miscegenation at Aq Kupruk (and elsewhere in north Afghanistan) has broken down the importance of maintaining lineage memories beyond three generations, although Tajik and Uzbak still view in-group marriage as the ideal. None, they maintain, would marry a Moghol or Hazara.

In mountains to the south, east and west live Hazara groups, mainly the Dai Zangi, but with Yek Aulang to the east.

are Mongoloid-looking, Dari speakers of the Hazaragi dialect. All are Muslims: some in the east are Ismailiya Shia but most are Imani Shia. They are not, as popularly believed (probably in order to justify discrimination against them by other Afghan groups), the descendants of the armies of Genghis Khan, but probably arrived subsequently during the Turco-Mongol periods of the II-Khanids and the Timurids (thirteenth to fifteenth centuries A.D.).

Small groups of Moghol live to the south of Aq Kupruk. Mongolian, like Turkic, is of the Uralic-Altaic language family. Although most Moghol today speak Dari dialects, their vocabulary contains a number of Mongol words and some of the older generation still know Mongolian. They may actually be descendants of the Mongols of Genghis Khan.

A small village of Pashai live near the Moghol; they were shipped north about 90 years ago from the fringes of Nuristan after they revolted against Abdur Rahman Khan. The Pashai speak a Dardic dialect of the Indo-European language family.

Other groups, calling themselves "Arab" Saadat, speaking an Arabicized-Persian, move through the mountains seasonally. Few, however, pass through Aq Kupruk. The peoples of the region consider them to be ethnically Tajik.

\section{The Rural Household}

The household dwelling compounds (Khanah) in Aq Kupruk reflect a mixture of Iranian Plateau and Central Asian influences. The basic house type in high, dry Afghanistan is square or rectangular, constructed of sun-dried bricks or pisé (mud walls pressed in wouden frames or more frequently simply piled higher and higher), covered with mud and straw plaster. The bricks are made in wooden molds, then placed on the ground to dry. Flat roofs of rammed earth (which must be remudded each fall) rest on mat-covered, wooden beams. A layer of interlaced twigs and branches between the beams and the rammed earth prevent mice and rats from infesting the ceiling. Stone foundations occur where stones are available. 


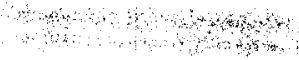

The basic Uzbak rectangular house type with several rooms leading off a veranda-like porch is common wherever Uzbak-Tajik mixtures exist in northern Afghanistan. Some families in $\mathrm{Aq}$ Kupruk (particularly Tajik) live in square huts with domed roofs, a variant of a type found across Iran into northern Iraq, Syria, and central Anatolia. Additional beehive segments can be added as new nuclear families come into being. The more well-to-do in $\mathrm{Aq}$ Kupruk have special guest rooms where they entertain, and in which guests can spend the night. Mud wall screens usually separate the guest room from the family courtyard.

Pressed mud walls of varying heights line the meandering lanes of Aq Kupruk and enclose the dwelling compounds to ensure privacy. The ground inside the compounds is watered down at least twice daily during the hot summer days. This minimizes the dust and hardens the ground as it dries. The people also place brush from the mountains over open windows during the summer, sprinkling it with water. The resulting shade inside and the process of evaporation help keep the room cool.

The $\mathrm{Aq}$ Kupruk compound, in addition to the residential quarters, usually includes storage sheds and outdoor privy, animal pens, cooking areas (an enclosed area for winter, exposed for summerl, and vegetable garden, occasionally with a small irrigation canal (jui). Fuel used in cooking includes dried animal dung cakes, busa (an oily bush collected from the hillsides), and charcoal.

Household goods consist mainly of cooking utensils, teapots, cups and saucers, religious mementos, heirlooms (guns, swords, brass and tin-plated copper objects), storage chests and containers, stone and pottery lamps. The more affluent will own kerosene lanterns, pressure lamps, and samovars.

In the summer, families sleep outdoors on specially constructed tamped earth platforms or on rooftops. A few sleep on rope beds with a wooden frame, but most use a thick mattress which they roll up and stack inside the houses during the day. Some people use mosquito netting. ${ }^{*}$ Fleas and lice periodically plague the people of Aq Kupruk.

Another major dwelling type, the portable yurt (khergah, Dari; ooee, Uzbaki Turkic), a reflection of the Uzbak's nomadic Central Asian past, is a wooden-framed, round-roofed, felt-covered hut. None of the people of AqKupruk are even seminomadic today, yet frequently theyput up yurts inside their compounds and live in them during the hot summer months. ${ }^{* *}$ Many Aq Kupruk farm families, however, still follow transhumant agricultural patterns. In summer, they move with their families to highland fields. Household goods and yurts are transported on donkey and, rarely, camel back. Even cattle are used as beasts of transport. The farmers set up camp near a threshing floor hardened through time, and in a month or two reap, thresh, and winnow wheat, and later pick melons. Almost all have returned to Aq Kupruk by late September.
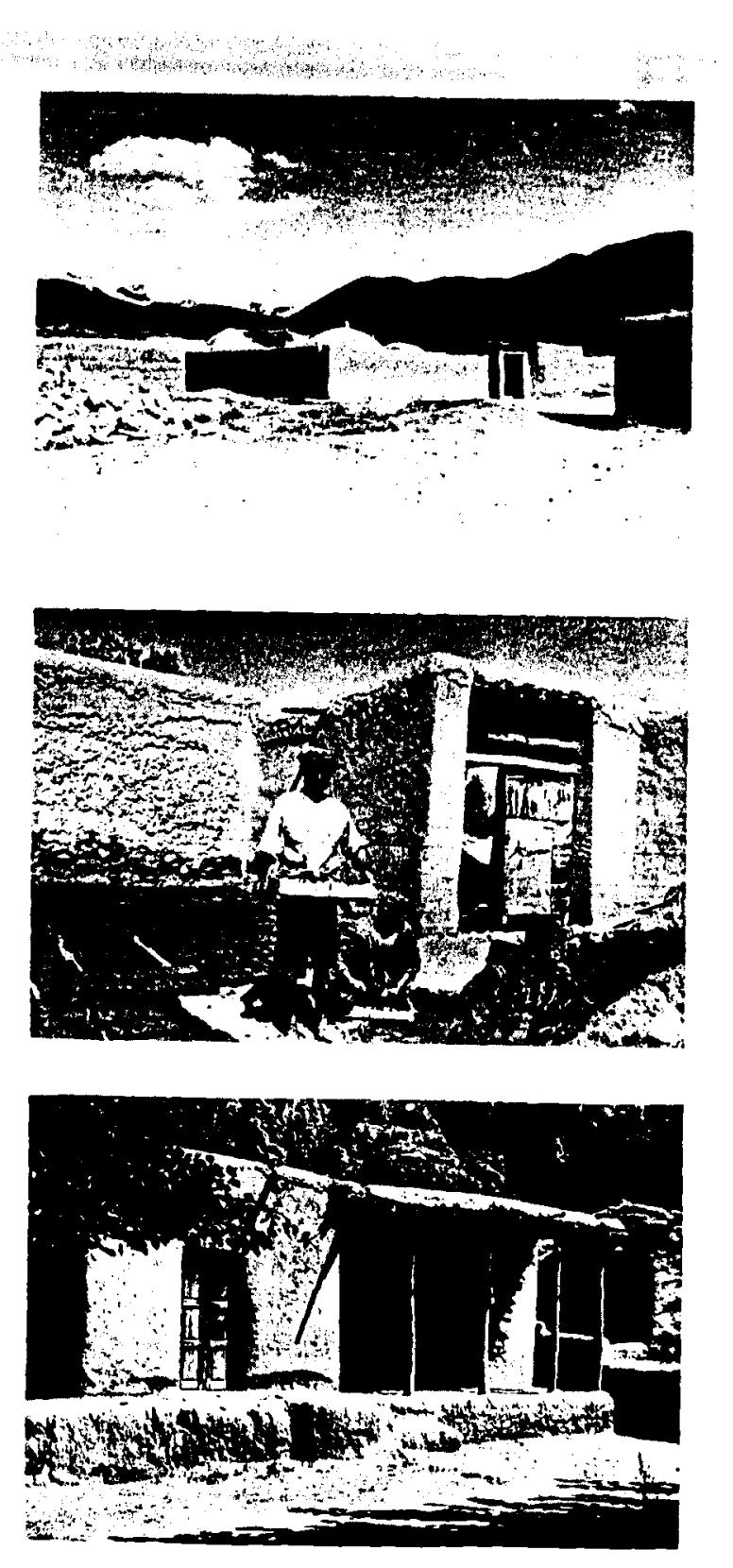

*Mosquitoes have been coming back to the area since the World Health Organization's malaria eradication project ended in 1962.

**The yurt is easy to keep clean: inside, personal belongings hang from wooden hooks supported in the frames or nestled in intricately carved and painted wooden chests, a specialty of the Hazara living at Sangcharak, another bazaar center farther west. 


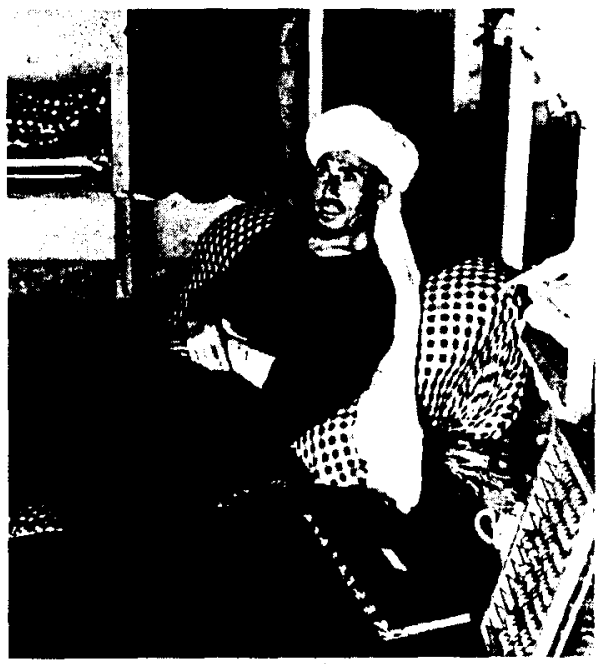

A shopkeeper at the bazaar.

\section{Film Dialogue}

ashhadu anna la ilaha illa llahu wa anna muhammadam rasulu llah.

(There is no God but God and Mohammed is his messenger.)

Sound of the morning prayer as dawn breaks upon the bazaar.

\section{Film Dialogue}

Only a few shops in Aq Kupruk open daily. Most, however, do business on the two bazaar days a week when artisans, farmers and herdsmen come from surrounding areas to barter or buy produce, wares and services, and to relax, gossip and exchange news in teahouses.

Land Owned by Shopowners: 1972*

Total Unirri- Irrigated \% OwnShop- gated ing Land owners

$\begin{array}{lrrrr}\text { Tajik } & 82 & 42 & 3 & 53 \% \\ \text { Saadat } & 28 & 22 & 4 & 79 \% \\ \text { Uzbak } & 13 & 7 & 1 & 54 \% \\ \text { Khoja } & 8 & 2 & 2 & 25 \%\end{array}$

*In 1965 all shopowners owned land.
Family organization at Sokhta and Aq Kupruk is fairly typical of north Afghanistan. At Sokhta a number of related nuclear families live together with their retainers. In Aq Kupruk, the single nuclear family,is more common, with possibly one or more grandparents living with one of their sons: in 1972 about 75 per cent were nuclear families; 20 per cent lineal joint; and 5 per cent collateral joint. Sometimes the grandparents move from one son's residence to another. Several factors have caused this evolution away from the idealized extended, three-generational family that characterized pre-1880 Afghanistan: the migration of many groups from south to north; the fragmentation of landholding because of the inheritance patterns; marriages outside the preferred inner family circle because of a shortage of marriageable cousins. In addition, most villages in the north have become ethnically mixed, and over 50 per cent of the village population are teen-agers and children, whose experiences in school tend to lead toward lasting, extra-kin friendships.

\section{The Aq Kupruk Bazaar}

Aq Kupruk, because of its intermediate position between true town and true village, illustrates many of the changes occurring today outside Kabul, the national capital. For two Afghanistans exist. Kabul, which is rapidly modernizing, and the rest of the country, which lags far behind.

The economy of Aq Kupruk can still be described as a Neolithic farming self-sufficiency in an Iron Age technology. After World War II, land began to lose its primary role as a traditional source of power in Aq Kupruk. In the past people had used their surplus cash to purchase more land. Today most farmers own land, as do most of the merchants, and surplus cash is used to purchase additional commodity and luxury items. And although much barter existed in Aq Kupruk's bazaar as late as 1959, cash and carry is the rule today and credit is available, at very high interest rates, with shopowners serving as money lenders.

No formalized association exists among the shopowners, in keeping with the general noncooperation of the peasant-tribal society. Nor does one find the guild-like institutions, such as those thriving among full-time specialists in other large towns and cities. However, a kalantar-i-bazaar or chief among merchants is informally chosen among the permanently resident shopowners and presides over the infrequent meetings held by any or all of them. The kalantar-i-bazaar also serves as intermediator between the bazaar merchants and the district governor. If a problem cannot be solved by the kalantar, he submits it to the town council for binding arbitration.

Most shopowners live in Aq Kupruk. About 35 per cent live outside the town, but many of these are seasonal shopkeepers, so only 13 live permanently outside Aq Kupruk. Two men come from Zari each bazaar day to sell rugs and cloth; three arrive from Sholgara on bazaar days, bringing in such exotica as the popular 
plastic sandals now manufactured in Kabul, Chinese notepaper, contraceptive devices, plastic dolls, pens, pencils, and erasers. Eight shopkeepers come down from nearby Sokhta village.

The veritable revolution in the Third World communications brought about by the battery-powered transistor radio has not missed Aq Kupruk. In 1965 about 20 transistor radios existed in the village -12 in the various teahouses and otel. By 1972, the figure had increased to at least 50 , all protected from dust by elaborately embroidered carrying cases. The combination tailor, watch-andradio repairman had a constant backlog of broken-down radios filling every nook and cranny of his shop.

The number of shops open in the Aq Kupruk bazaar reflects both seasonal activity and the commercial adjustments that followed provincial administrative changes in the 1960s. At its peak, the bazaar at Aq Kupruk has 101 functioning shops, of which 51 open daily. When the agricultural season has ebbed and all the seminomadic pastoralists (maldar) have passed through the town, the number of shops open daily drops to about 22 .
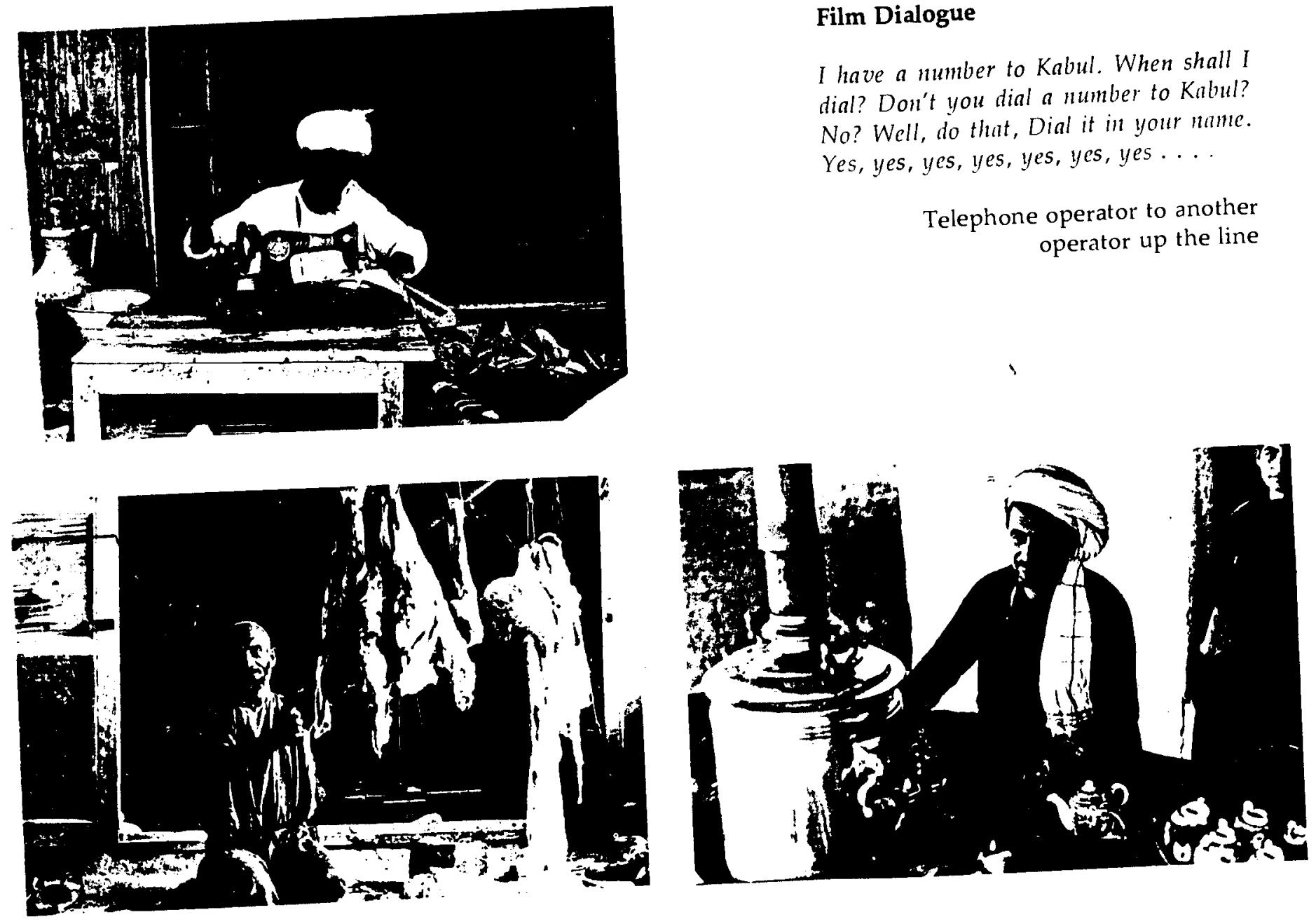


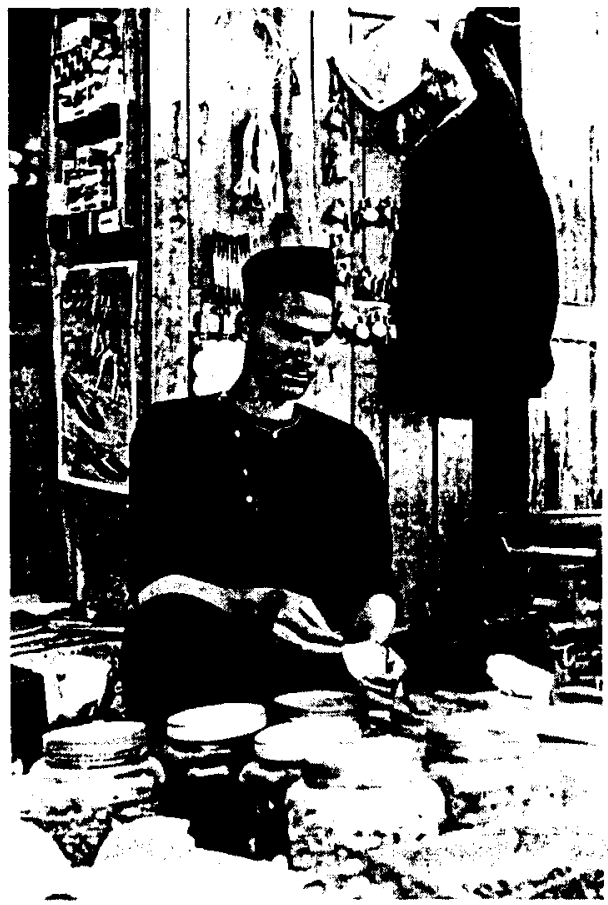

Abdul Karim, owner of a shop in Aq Kupruk.
After farmers and others sell their produce and wares on the open market (maydan or maidan), they go to the covered bazaar to shop and then return to their homes in the hills or elsewhere. Items sold on the maydan include agricultural and dairy products; flat-weave rugs (gelims) from the Hazarajat (those made by the women of Sangcharak are especially prized, but Turkoman gelims are the most prized of all); pottery and matting from Sholgara; grapes from Sangcharak; wooden spoons made locally. Some Hazara bring rock salt from the surrounding mountains.

By late July, tomatoes, melons, cucumbers, squashes, and rice are also sold in the maydan, as well as in the seasonal shops. The increase in the number of these shops (mainly selling foodstuffs) since 1965 (from 8 to 18) and the increase in the number of butchers (from 5 to 11) indicates the return of relative prosperity to Aq Kupruk. Even in the drought years of 1970 and 1971, which drastically affected areas farther south and west, Aq Kupruk was able to feed its own and even export some wheat to nearby stricken areas.

Another sign of increased prosperity is the rise in the number of itinerant artisans passing through $\mathrm{Aq}$ Kupruk: a cupmender, a knife sharpener, several cobblers lone'from as far away as Gurziwan, south of Maimana). Many itinerant specialists travel across the mountains and foothills of northern Afghanistan, often remaining in one area for several bazaar days. Sometimes they range from Herat to Kunduz and back. Barbers, local and itinerant, shift from restaurants (ote/) to teahouses (samovar), /shaving heads and trimming beards. Some barbers are musicians, and all perform circumcisions.

Bazaar shops and most homes in Aq Kupruk are heated by charcoal braziers (manghal), over which low wooden tables are placed. A large blanket is spread over the table so that it drapes to the floor. Whole families sit around the sandali, as the system is called, covering legs, arms, and much of their bodies under the blanket to absorb the heat.

Three lorries ply between Sholgara and Aq Kupruk on bazaar days: two are owned by shopowners in Sholgara; the other is a recent acquisition of the Sufi Sahib. Each Friday about 18-20 shopowners from Aq Kupruk make the trip to Zari, a bazaar town to the west, on Sufi Sahib's lorry. They are all Tajik bonjaragi* and bazazi** owners and make the trip only during the late summerearly fall peak periods. The Aq Kupruk visitors not only sell their wares in the open air bazaar, but purchase items to sell in $\mathrm{Aq}$ Kupruk, especially dried apricots, ripe melons, and animal skins. Sholgara has the same bazaar days as Aq Kupruk (Monday, Thursday), and a much more widespread and active daily bazaar. Sholgara's growth began with its administrative upgrading in 1961. A total of about 900 men from small villages and households in the Aq Kupruk area moved to the vicinity of Sholgara and there was an immediate upsurge in bazaar activity. At present some
${ }^{*}$ Bazazi: cloth shops sell Afghan and imported cloths, rayon, cotton, wool, silk. 
200 shops are open daily, and more than 300 open each bazaar day. Sholgara has become the major communications center in the area and the largest commercial center south of Mazar-i-Sharif.

\section{The Qishlaq of Mullah Ata Mohammad Boy}

Mullah Ata Mohammad Boy* and his family live in a qishlaq about an hour's walk south of $\mathrm{Aq}$ Kupruk in the area called Sokhta, or "burned land." Legend has it that about "one hundred years ago" (the time usually given for any important, though unrecorded event in the past), a large forest existed at Sokhta, but lightning started a fire and burned the hillsides. (If, in fact, such an event did occur, the loess should have been appreciably richer.) Qishlaq, a Turkic term, refers to the winter quarters of nomads and seminomads, but is also used in Afghanistan to denote independent households which exist outside the village proper.

Mullah Ata Mohammad's father had purchased the bulk of the Sokhta land about 40 years ago, built several mud houses, and moved there from Aq Kupruk with his family because of some local difficulty which was never made clear. While Mullah Ata Mohammad performed his military service, his father died. The Mullah returned home in 1964 and immediately purchased the remainder of the Sokhta land (making a total of 70 acres) from some Tajik in $\mathrm{Aq}$ Kupruk who needed cash for their sons' weddings. Mullah Ata Mohammad's entire group moved up the hill to a better drained area in a new compound.

In 1972 the household consisted of 23 people, including three nuclear families, two unmarried brothers, four unmarried sisters, and three retainers (two teenage boys and one middle-aged farmer):

Mullah Ata Mohammad Boy (about 30 years old), wife, six-month-old son, three- and five-year-old daughters; owns 15 acres.

Juma Boy (about 38), wife, five-year-old son, six-year-old daughter, nine-month-old daughter; owns 15 acres.

Jura Boy (27 years), wife, two- and three-year-old-sons; 15 acres.

Rozi Boy (22 years), unmarried; 15 acres.

Pir Mohammad (12 years), unmarried; 15 acres.

The rest of the land had been divided among five sisters, including one who lived in Aq Kupruk, a second wife to a leading mullah; but she spent almost as much time at Sokhta as in her husband's house.

\section{Film Dialogue}

Many yilaq (summer quarters) exist in the hills around Aq Kupruk. The one at Sokhtn evolved into a permanent, year-round residence (qishlaq) for part of an extended family and its hired help. From the qishlaq, flocks are grazed and sheared, and highland, unirrigated wheat reaped, threshed and winnowed.

*Boy is the Uzbak (and sometimes Tajik) equivalent of Khan, a loose status designation for adult male members of important families, not necessarily leaders of village or tribal units.

\section{Film Dialogue}

When we arrived here...

We were amazed how tall the wheat had grown.

It grew so tall ...

That the stalks bent over.

Here we grow the best wheat.

In a day a man can cut nearly 100 pounds.

If God wills we shall cut 7, 14 or 21 tons.

We call this area Sokhta ... the burned land.

The past two years have been hard.

No one can explain God's will.

No rain has fallen and many are hungry.

We get up early in this hot climate.

We have tea and bread and work until 4 in the aftemoon.

We supervise our shepherds and farmers.

In the spring my brother sends me sheepskins.

I preserve them in salt and prepare them for sale.

This is the kind of work we do.

Mullah Ata Mohammed 


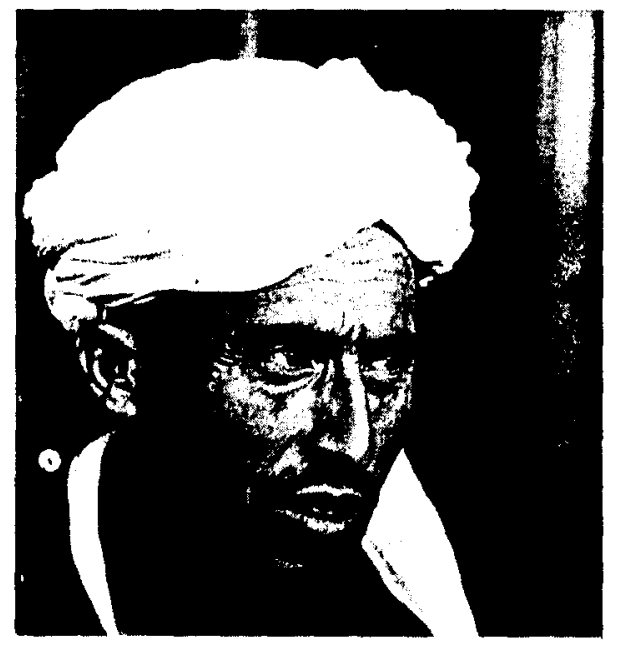

Mullah Ata

"In Islam any man can proclaim himself "Mullah," but consensus of the people in the area must approve the selfappointment.

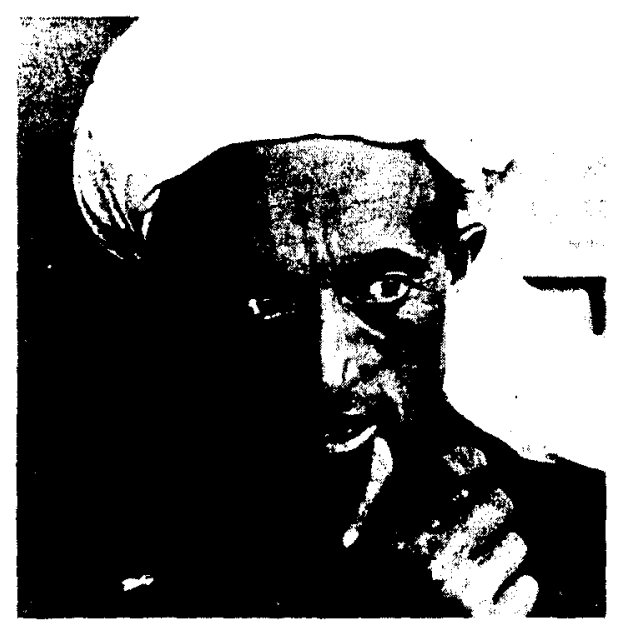

Jura Boy

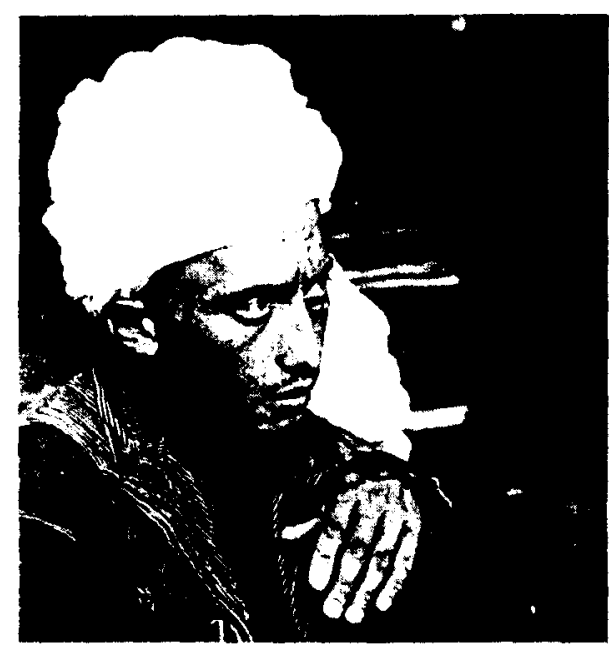

Rozi Boy.
During the summer harvest, Juma Boy and Jura Boy move into yurts; Juma Boy just outside his house, Jura Boy on a hilltop near his fields. All the brothers work in the fields, but the youngest, Pir Mohammad (not yet old enough to be called "Boy"), had been spoiled by his older brothers and did not know how to cut wheat properly, a shortcoming which made him the butt of many jokeseven from the retainers and the hired laborers. Juma Boy is the eldest, although he is not head of the family. He is generally considered to be a clown or "slightly touched by the hand of Allah," that is, nutty. He does nothing to counter these suspicions.

Of the five brothers, only Mullah Ata Mohammad can read and write. He was trained in the Aq Kupruk religious school (madrassa), and adopted the title, "Mullah," although many in Aq Kupruk criticize him for this. "Mullah Ata Mohammad did not lead prayers in any of the mosques in Aq Kupruk, but he did lead the five daily prayers when present in his qishlaq. All three of the brothers with sons want them to attend the madrassa, and if possible go on to study with learned religious scholars (mau/vi) in Mazar-i-Sharif. They all consider the government school in $\mathrm{Aq}$ Kupruk to be useless, and consider the study of Islam, a way of life, to be much more practical than the history, arithmetic, and other subjects taught in the secular school.

Mullah Ata Mohammad traveled to Mazar-i-Sharif, Kabul, and Kunduz during his army service. Juma Boy's army career, some 14 years earlier than the Mullah's, was spent in Kabul. Jura Boy had been to Mazar-i-Sharif and Kabul, but in 1972 the two younger brothers had never been farther afield than Aq Kupruk.

The qishlaq itself consists of a large, walled compound, divided into two sections. The inner area has a rectangular house with rooms leading onto a veranda, and each woman, including the unmarried sisters, has her own set of rooms. The outer area, separated from the inner by a separate wall with a large wooden door to guarantee privacy, includes the guest house, the milking area, a courtyard, and animal stables. Two bachelor brothers sleep in the same area as the retainers but Juma Boy has built a smaller compound adjacent.

No streams reach into the high area of Sokhta, and the five brothers, using iron adzes, picks, sledge hammers, wedges, and crowbars, have ingeniously dug seven cisterns in the solid limestone. Rain water and snow melt are led into the cisterns by means of shallow, downhill grooves. At five wells, water isdrawn using a leather bucket and rope, but two of the cisterns have a windlass contraption and goatskin buckets. When the sheep are in the qishlaq, they are watered from the cisterns. Cattle are always kept in the qishlaq, and in winter are kept in storage pens which have been cut horizontally in the hillsides. Grain and flour are also stored in such artificial caves.

The five brothers in 1972 owned a total of 210 sheep and goats; half were qarakul (the so-called, misnamed, Persian lamb), the rest mainly fat-tailed sheep. The goats are milked while in the Sokhta, and various dairy products form a major part of the diet. 
A shepherd from Maimana, Mohammadzai Durrani Pushtun, had cared for the flock for seven years. A bachelor, he had not visited his family for three years. His contract called for 20 days of vacation a year, but he usually spent the time with friends in Sholgara. His salary was 30,000 afghanis* per year or about 145 afghanis per animal, but he was economically liable for any missing sheep and goats. The shepherd had a hired assistant and three large mastiff-like herd dogs (sag-i-ramah) ${ }^{* *}$ to help protect the herd from human and other animal predators.

The annual cycle of the herd is interesting and nothing like that of the seminomadic maldar. In October, the shepherd leads the herd over the central mountains via Band-i-Amir all the way to the hills outside Spin Baldak near the Durand Line, which separates Afghanistan from Pakistan. When snow comes the herd eats alaf, busa, and other grasses under the snow, pawing through the snow to reach the hardy plants. In late March, the shepherd moves the flock to the Band-i-Amir area, and here, in April, the lambing season takes place. ${ }^{* *}$

Jura Boy joins the herd in the Band-i-Amir area, and sends qarakul lambskins to Mullah Ata Mohammad, who prepares them for sale in Mazar-i-Sharif. The lambs are killed at birth, so that the skins will be soft and bring higher prices. ${ }^{* * *}$ About mid-July, the herd moves to Sokhta, where the milking takes place. In August the shepherd, his assistant, and the five brothers shear the sheep with locally made, scissors-type shears, the blades of which are not permanently joined for better flexibility and to minimize nicking the sheep. The wool is used to make felt and to spin into thread for weaving a large number of domestic items. The surplus is sold in Aq Kupruk, Sholgara, and Mazar-i-Sharif. The cycle begins again in October, and the herd takes the long trail toward Spin Baldak.

Mullah Ata Mohammad maintains close touch with what transpires in Aq Kupruk. About 1965, he acquired a cloth shop in the bazaar. Almost daily, he walks down (or rides a donkey) from Sokhta, opens his shop, and holds court. He is a moneylender, and many people in Aq Kupruk owe him money. Often the loans are not meant to be repaid; loans obligate the borrower to support the lender in the event of factional disputes. If a borrower defaults or leaves the area, however, considerable effort is expended to collect the money.

Mullah Ata Mohammad hires five laborers each year from Kishindi to help reap, thresh, and winnow the fields of all five brothers, taken in turn. Each laborer received 70 kilos of wheat for each six days of work. One man can cut about 45 kilos per day, of which about 11 kilos goes to the laborer, or about one-quarter to one-fifth of the crop. The laborers usually bring their families with them and set up chapari near the khirman. As part of the deal, the same laborers come back in the spring to help plow and plant the wheat. The grain is then carried by pack animal to the mill in Aq Kupruk.
*At the 1972 rate of about 90 afs. to $\$ 1$, his annual income was approximately $\$ 333$; at the present rate of about 50 to 1 , about $\$ 600$, which compared to the salaries of Afghan civil servants is not bad. A Kabul University professor, for example, gets about $\$ 40$ per month as do most mid-range bureaucrats.y

**The Mullah Ata Mohammad had three such dogs to guard his compound. He said neither rocks nor bullets could stop them, but these dogs seldom attack unless ordered to by their masters. Instead, they set up a howl as strangers approach. Then the inhabitants come out to see who has arrived-and call off the dogs.

${ }^{* * *}$ One Afghan herding custom has frustrated a generation of foreign livestock specialists. The lambs, kids, and calves are muzzled or kept away from their mothers and only permitted to feed once or twice a day, potentially inhibiting their growth. Foreign technicians have been unable to convince Afghan herdsmen that the milk will continue if the young ones are permitted to suck frequently.

****A Qarakul Institute with headquarters in Kabul has been attempting to improve breeding and preparation procedures since 1966, and as a result, the Afghans have been able to capture a larger percentage of the world's market through the auctions held periodically in London. The skins are graded carefully before being flown to foreign makers. The golden skin is the most highly prized, followed by varying degrees of browns, blacks, and grays (Zondag, 1974). 

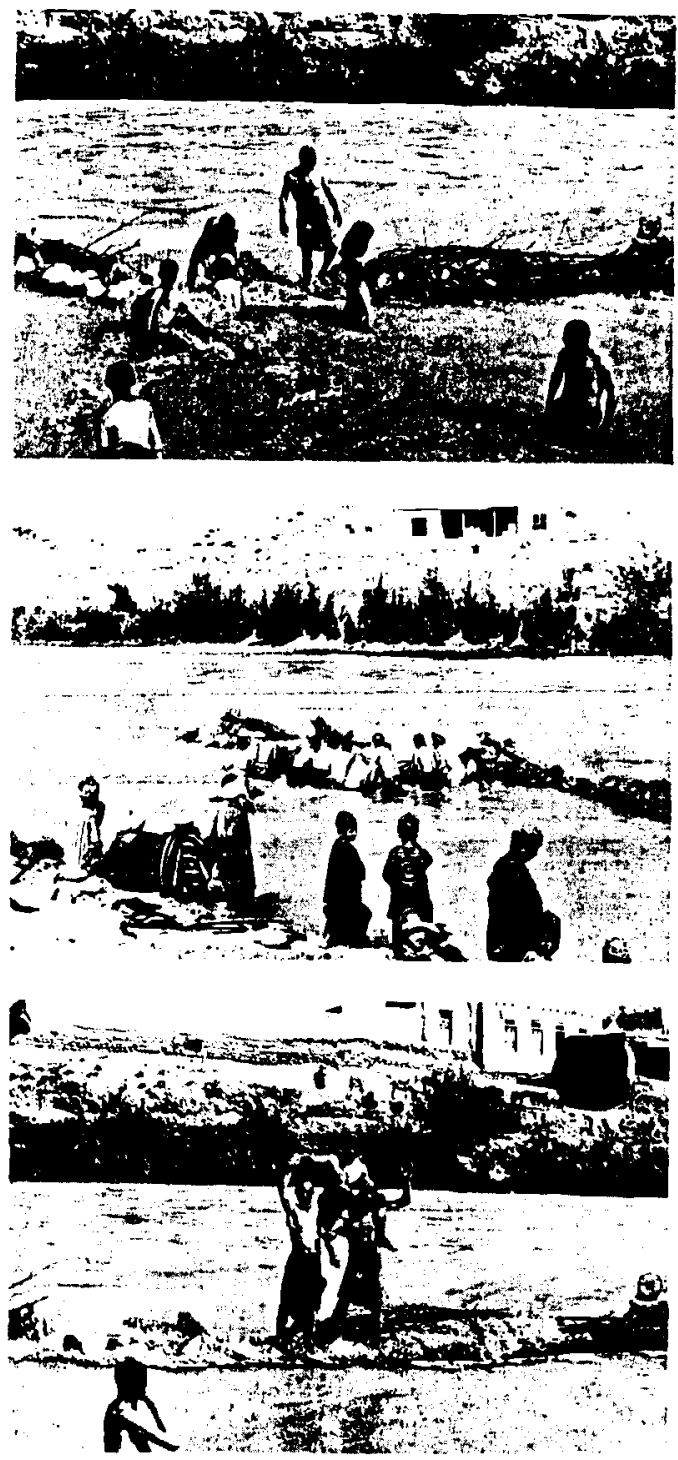

*See "Wheat Cycle," film and film essay.

**One popular game uses a large die, with figures (king, jack, queen; and animals (donkey, elephant, cock) on each of its six sides. Gamblers bet on which side will land face up by placing money on a cloth divided into six squares with the same painted figures and animals

\section{The Jui and the Mill: Communal Work}

Contrary to popular belief, villagers are fundamentally noncooperative creatures outside their own immediate kin-groups and are not communally oriented. The annual cleaning and repairing of main canals on either side of the river, the jui, is a good example. The jui channels water into the gardens and orchards of the irrigated land $(a b i)$, and into the mills which grind wheat into flour. All those who live along the river bank and benefit from the water to irrigate their gardens assist in the work, as do those who own or expect to use one of the mills.

The work begins in early July when a diversion weir is constructed at the entrance to the jui. Boulders chinked with sage, which expands when wet, are held in place by large, tripod-shaped wooden braces. In the swollen river the work may be dangerous and occasionally men are injured by fast moving boulders or the collapse of part of the weir under construction. Spectators sometimes strip to the waist and join in as the work progresses. Gratuitous advice flows from all directions, but out of the seeming chaos, the weir takes shape. It must be repaired periodically as the swift river erodes the sage and tugs at the boulders and wooden frames.

In 1972, between July 25-27 about 50 men built a dam of stones and sage to block water from the jui. Then they cleared the accumulated silts and large stones from the bottom and sides so that the paddles on the flywheels of the mills would not be damaged nor the water flow impeded. * The clearing work was done with shovels, at times with a rope attached; two men pulled the shovel blade and one man guided the handle. Two-man, stretcher-like carryalls are the common means of removing rocks and silt from the lower parts of the canals.

The men worked until 7:15 P.M. on July 25 and 26 , and finally completed the task on July 27 , when they destroyed the dam and allowed the water again to flow into the jui and down the sluices to operate the mills. No one was paid for his effort, but all enjoyed the comradely work and horseplay.

\section{Jeshn: National Independence Day}

The day before Jeshn, in August 1972, people began pouring into Aq Kupruk. The announcement of buzkashi was largely responsible for the turnout. The District Governor (alakadar) forbade public gambling, but there was gambling nonetheless. ${ }^{* *}$

On Jeshn morning (August 23), the District Governor appeared in his best Western-style suit and shoes. The bazaar had been decorated with colorful cloth hangings donated (not always voluntarily) by local cloth merchants. The town crier roamed up and down the bazaar street, announcing that all should come to 
the shop of Sufi Sahib, an influential local leader, where a radio would broadcast an address by King Mohammad Zahir, since deposed, to be followed by the District Governor's re-reading of the text. The people, however, were more interested in wandering through the colorful bazaar and, since Jeshn is traditionally a time to buy new clothes, strutting about in their fresh finery. Looking through Viewmasters at slides of Mecca, Medina, Mashhad, and such Western cities as Paris, London, and New York was also a popular diversion. (The owners of the Viewmasters sometimes attracted customers by promising views of sexual delights as well, but did not deliver.)

Below, the 1972 Alakadar, and the truckload of celebrants arriving for Jesin.
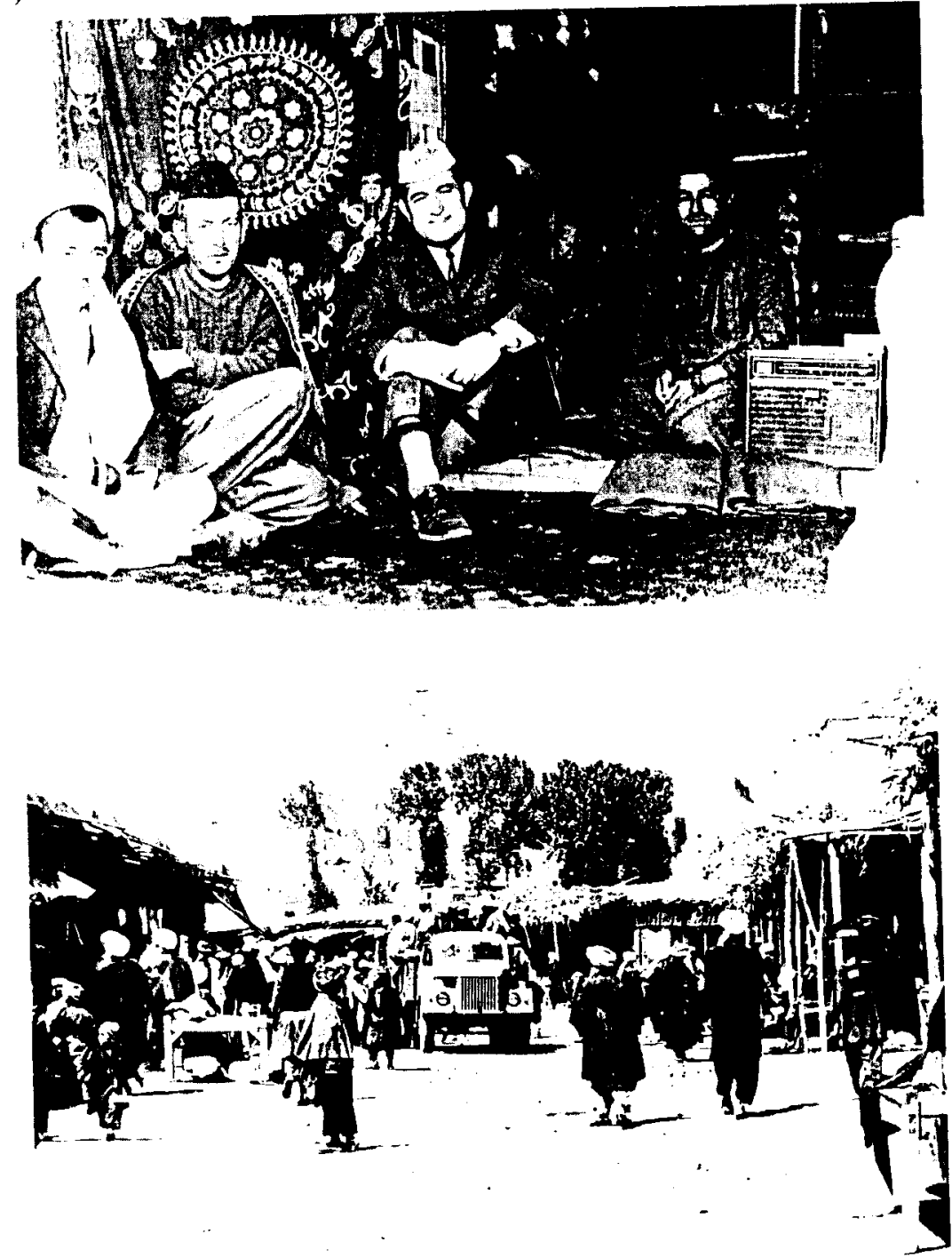

Below, colorful cloth hangings on shops.

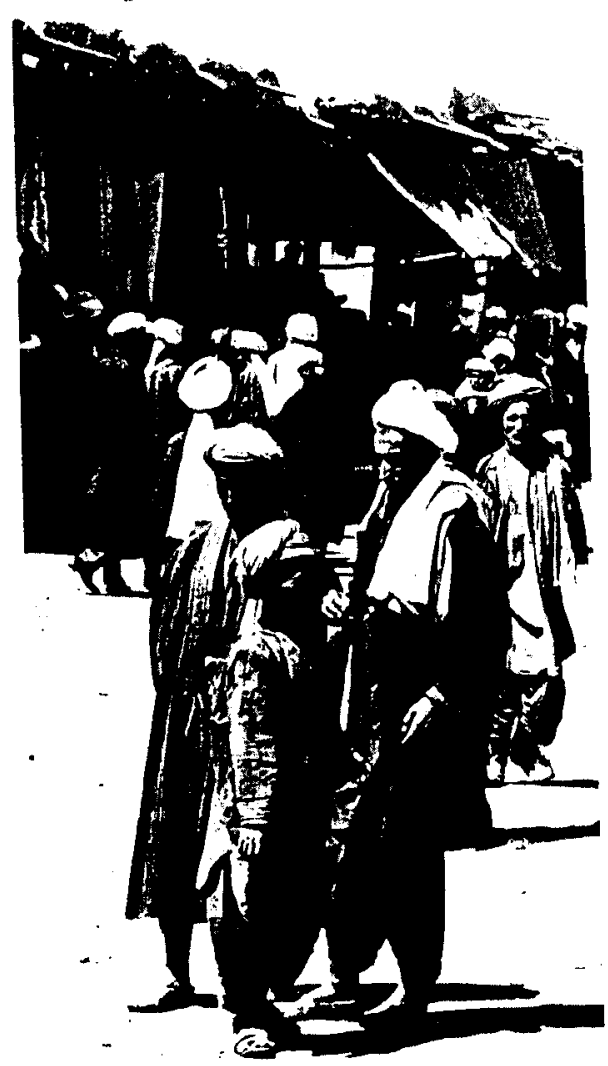




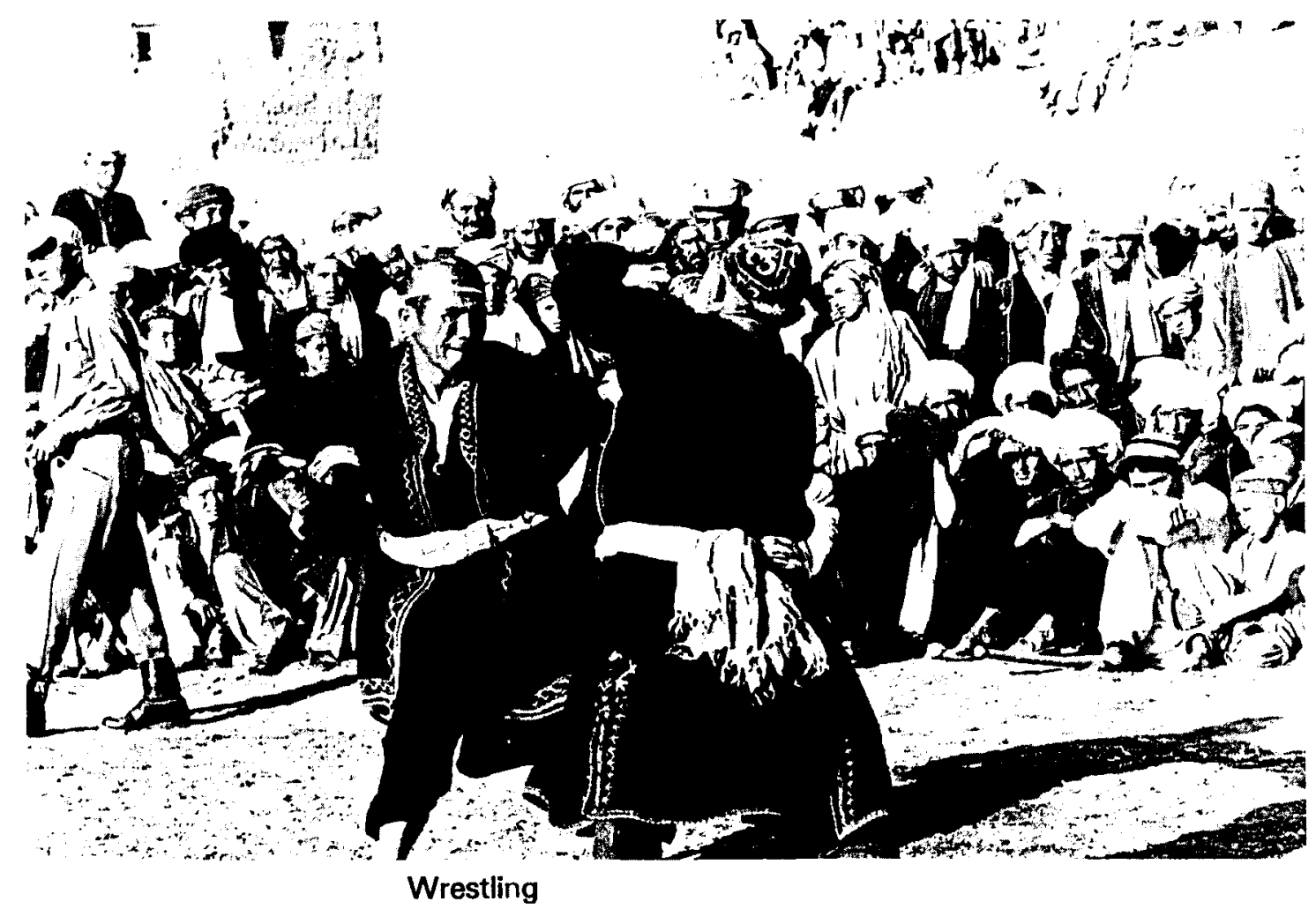

*In 1972, a mullah from Zari, who had been baiting the Aq Kupruk wrestlers, was challenged. After putting up a good fight for several minutes, the mullah walked away, saying he was tired. Being a mullah, he escaped a beating, but he was unmercifully kidded the rest of the day.
The first afternoon featured wrestling in front of the boys' school. The spectators gathered in a wide circle around the participants. Coaches (retired champion wrestlers) from various villages select contestants on the spot, for they have watched the young men develop and know their fighting capabilities. The contestants are nervous, for losing a match means losing face not only personally but also for the entire village.* A man picked to wrestle often exhibits signs of panic, with eyes rolling and lips trembling. Struggling to escape, he may pray and moan for some time before the match can begin. Then the two coaches drag their chosen victims to the center of the ring and stand them side by side to see if they are about the same height and weight. Either coach or contestants may protest an obvious mismatch, and the glassy-eyed contestants usually leave the decision to others. If both sides agree, the contestants return to their respective groups of friends and relatives who prepare them for the match.

Clothing must be worn in a prescribed manner. Many wrestlers wear two turban caps as protection in falls. A many-colored cloak (chapan) must be worn, with a cummerbund or kerchief tied loosely around the waist. Pajama-like pantaloons (tombon) complete the costume. The men wrestle barefooted.

Before the action begins, the ground is sprinkled with water to keep down the dust, and more water is sprinkled between matches. The two coaches act as referees and first search the contestants for hidden weapons. 
The two wrestlers stand apart and pray for God's support, touching their chins as a sign of respect and submission to God's will. They advance on each other, formally shake hands (both hands) and bow low. They then walk in circles around the edge of the crowd, loosening up, readjusting their cummerbunds, tightening them again and again, stalling for time. The impatient spectators urge them to fight. At long last they face one another, rocking from side to side and flailing their outstretched arms over their heads, looking rather like a pair of mating scorpions. The object of the match is to throw one's opponent and pin his shoulders to the ground. The rules are simple: wrestlers may grab arms, legs, and the chapan, but not the tombon. Clothing is often ripped and must be replaced before the match continues. Spectators gladly loan chapan to be torn to shreds, for the honor of the village rests on the outcome.

Balance is all important. Generally, the contestants grab each other's forearms, and move sideways in a crablike rocking motion, testing for strength and balance. Often a man will leap high in the air, ending up behind his antagonist with a headlock. Sometimes one such move ends a match. Most matches end within five minutes but some may last as long as one-half hour.

There is no specified time to declare a pin. If a man's shoulders touch flat on the ground, he is pinned. When it seems apparent that one man has pinned another, the coach of the winner lifts his man by the waist, or pats the winner on the back, and runs around the spectator's circle. The victor clasps his hands over his head as the crowd applauds. The coach deposits the wrestler in front of the alakadar and the village elders, who disseminate the prizes, usually cash or a turban cloth or both. The opposing coach may protest. The cheers or jeers of the crowd determine whether or not the match should continue. The District Governor and the elders make the final decision.

Fights occasionally break out among the crowd, and police restore order with a flailing of fists and belts. Much money passes hands, for betting on individual performers is common.

In rural Afghanistan, entertainment is at a premium. Only the transistor radio and the hand-cranked gramophone have penetrated the mud hut and the teahouse. The peasant-tribal society honors its'folk musicians and tale-tellers and people often travel for miles to hear a performance, which usually accompanies celebrations of births, circumcisions, or marriages. Celebrants sometimes hire professional or local performers, almost always men. Village women play musical instruments, sing and dance inside their own compounds, but seldom - if ever-perform in public. In fact, one seldom sees a woman in a teahouse where professional entertainers perform.

The absence of women performers long ago led to the practice of female impersonation. Such professionals dance-and sometimes sing - to the accompaniment of drums or tambourines, 


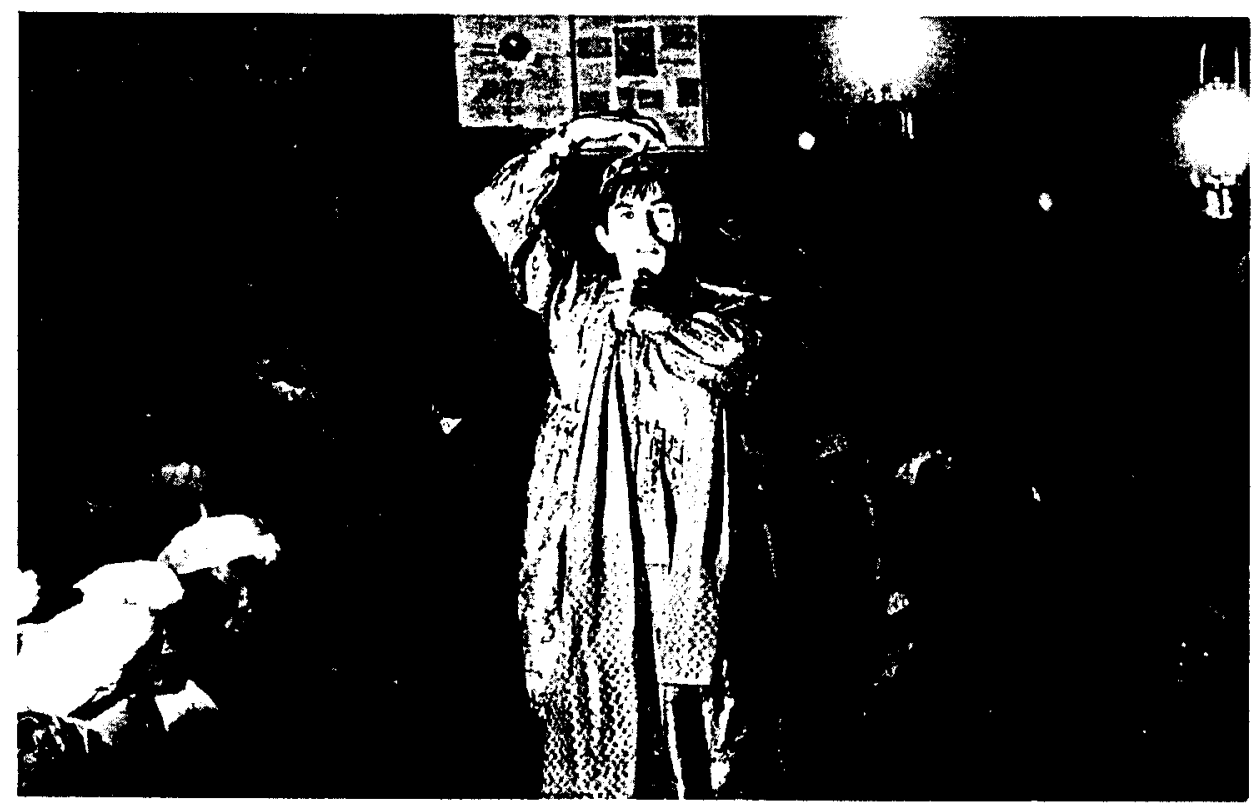

A dancing boy performs in an Aq Kupruk teahouse.

*Buzkashi horses are pampered and expensive. Often better fed than people, they eat barley twice a day, melons in season, and occasional mixes of barley, raw eggs, and butter. Horses are trained for about five years before being committed to the playing field. stringed instruments, and sometimes a surnai, a reed instrument resembling and sounding like a bagpipe chanter or oboe. The dancing boy usually wears anklets of bells, bells on his clothes, and often uses polished wooden castanets to beat out the rhythm. Generations ago many dancing boys were eunuchs, but castration is infrequent today. Some dancers wear talcum powder on their faces to hide their beards. Most shave several times a day and use mascara, rouge, and lipstick to enhance their beauty. Some dancing boys supplement their income serving as male prostitutes. Sometimes they form a partnership with a lover, such as a lorry driver, and travel together from town to town.

Most dancing boys are itinerants who perform in teahouses on evenings before bazaar days. Often they sit in the bazaar during the day, announcing by song the time and place of their evening performances - or, in a modern innovation, playing typical songs and dance music on portable cassette tape recorders. The dancing boys earn their money by collecting a certain percentage of the admission paid at the door of the teahouse. The fee was afs. 10 during Jeshn 1972 in Aq Kupruk and the troupe consisted of two dancing boys and two instrumentalists for a dhambura (twostringed instrument plucked with bone plectum) and a zerbagali (single-headed, hourglass-shaped, pottery membranophone). The audience participates with enthusiastic hand clapping, finger snapping, whistling, and foot stamping.

\section{Buzkashi}

One of the oldest sports of Central Asia, buzkashi is essentially a game of horsemanship* which involves two teams and emphasizes individual performance. A goat, or more often today a 
calf, is decapitated, gutted, and placed in a circle marked on the ground. Horsemen gather from the two teams, which can vary in size from three or four to a thousand, depending on the size of the field, the event celebrated, and the prizes offered. (In the early fall, after the harvest, villagers all over northern Afghanistan play sandlot buzkashi over ploughed fields). At a given signal the game begins. The horsemen try to pick up the carcass and ride with it to a boundary point (usually less than a mile away), then return to drop it inside a circle at the starting point. The rules are rather flexible, and the players ride with the élan of their Central Asian ancestors. The earth almost seems to move as they thunder by. Watching the game, one is impressed with the man-horse teamwork and can see how this game provided excellent training for the mobile shock cavalry which developed in Central Asia and Mongolia. (Even Alexander the Great could not defeat it. The cavalry Alexander met fought in the manner of the American Plains Indians, riding in circles around his less mobile forces, firing arrows from all angles and positions.)

Buzkashi can probably best be described as a combination of polo, mounted football, and unorganized mayhem. Injuries are common and the frequently used whips draw blood from both horses and men, even though most riders wear heavily padded fur hats and clothing, plus high boots with tall heels to hook in the stirrups. Usually buzkashi is played on the wide open fields of the north up hillsides, down valleys, and even across graveyards. A variant, buzkashi-yi-darya, is played in the river at Aq Kupruk. The rushing water and moving pebbles and boulders make this variety especially dangerous.

Although technically a team sport, the individual who scores a goal gets a prize. The sport is highly representative of Afghan culture, perhaps best described as fierce individual competition within a framework of loose cooperation. All successful buzkashi players and wrestlers gain status, and if a man is successful in both, he is doubly honored. (Abdul Karim, a landholding farmer who also owns a shop in the Aq Kupruk bazaar, is seen wearing white and riding a white horse. Twice in the same day, he is awarded a prize by the District Governor.)

\section{Belief Systems in Aq Kupruk}

Islam as practiced in rural Afghanistan, among villagers as well as seminomadic peoples, often appears strange to sophisticated religious scholars, for local pre-Islamic beliefs are interwoven with Muslim orthodoxy. Traditionalist religious leaders tolerate and support these beliefs, particularly predestination, out of inertia and ignorance and also because they help justify and perpetuate the old class and power structure.

The village mullah is often a nonliterate or semiliterate farmer who functions as a part-time religious leader. Islam has no 
*To be called Sufi Sahib (one who studies the mystical aspects of Islam), a man must read the Koran 113 times and maintain 40 days of silence. Aq Kupruk has one Sufi Sahib. In addition to extensive landholdings and a block of shops in the bazaar, he owns a Russian lorry which carries goods and passengers between Sholgara and Aq Kupruk, and between Zari and Aq Kupruk, on bazaar days. Personal wealth, literacy, and religious status combine to give considerable power to such individuals in $\mathrm{Aq}$ Kupruk. organized clergy, and every man can be a mullah.* Anyone can lead a prayer, if accepted by the community. But hierarchies have nonetheless arisen and, in Aq Kupruk, the following are accepted as religious leaders in ascending order of importance: talib (student in the madrassa, or mosque school, which formally trains mullahs); Mau/wi (four teachers in Aq Kupruk madrassa); Maulana (very learned religious scholars, none in Aq Kupruk, nearest in Mazar-i-Sharif); Afha (leader of large sect, nearest in Mazar).

A surprising number of Aq Kupruk men over twenty years of age have made the hajj (Pilgrimage) to Mecca, Islam's paramount holy city. In the Alakadari of Kishindi over 1,000 men lout of the officially estimated population of 19,005 ) had made the hajj, an indication of the relative wealth of the area when compared with the rest of Afghanistan and the Middle East in general.

In 1972, there were six functioning mosques in Aq Kupruk and two in the hills nearby, one at Sokhta and another to the west of Aq Kupruk. In addition, there are a number of saint's shrines, although people seem to remember little of their origins and none have special festival days. An exception is the shrine to Khoja Boland, about whom the people have an interesting legend. Khoja Boland, a saintly soldier in life, always warns Aq Kupruk when danger approaches by firing his rifle. When a cholera epidemic occurred in northern Afghanistan in 1965, the people of Aq Kupruk held a ritual feast (khyrat) to ward off the evil spirits causing the disease. All contributed what they could to the feast and the best cooks (always men) prepared the meal-ritually sacrificed animals, pilau, and sweet halwa. Everyone, even visitors, received shares. The mullahs at the feast asked God to keep the cholera away: only four people died when the epidemic reached $\mathrm{Aq}$ Kupruk, and many local residents swore on the Koran that they heard Khoja Boland fire his rifle in the early afternoon before the first death.

Supernatural creatures also harass the people of Aq Kupruk. The jinns, undefinable spirits, try to possess the living. Some are evil while others are merely jokesters. All possessed persons must be exorcised because jinns are considered to be the main cause of insanity and some diseases. The jinn replaces the scientific "germ" for nonliterate Afghans. Moreover, it is commonly believed in $\mathrm{Aq}$ Kupruk that no one dies a natural death. The causes must always be sought, and the evil jinn driven away from the corpse so that the soul and body can enter Paradise cleansed. (In addition, the people never remove vegetation from graveyards, for they believe that jinns imprisoned in the roots will escape and cause the death of someone in the family.)

Talismans (taawiz) are in common use. Most are purchased from the mullahs, who double as practitioners of white magic. Many elements of Central Asian shamanism and animism lurk in these corners of belief and ritual in Aq Kupruk. The people sew amulets on their clothing or wear them about their necks. Taawiz 
can be found for practically everything from curing the common cold to making a man irresistible to women - or a specific woman. Certain magic formulae, all considered locally to be Islamic, must be chanted (or blown) over the taawiz by a mullah to make them effective.*

The people of Aq Kupruk live in a peasant-tribal society, the attributes of which are broadly applicable to most of the developing world. These attributes tend to perpetuate an inwardlooking society, in which men and women are born into a set of answers. In the pluralistic Western, developed world, people are born into a set of questions (an outward-looking society). Yet $\mathrm{Aq}$ Kupruk is neither changeless, timeless, nor genuinely isolated. It has links which already filter up to the national level. Communications and transportation improvements as well as administrative changes are disrupting life from the outside and secular education's influence is subtle but perhaps ultimately more radical.The town and region are adjusting, and more and more often people too must respond individually to a new set of alternatives. Life along the Balkh River in northern Afghanistan is, as it long has been, at a cultural crossroad.

[Photos by Louis Dupree, Nancy Hatch Dupree, Josephine Powell]
*A blind Qori Sahib (one who can quote the Koran in its entirety) sold me a wolf's astragulus for afs. 500 in 1972 . He had prayed and blown over the amulet for 24 hours without a break. One which had simply been blessed sold for afs. 30 . The function of the amulet is to preserve the owner from an enemy's evil eye. A hole had been drilled through the astragulus and by viewing the enemy through the hole, one man neutralizes his power. The pubic sympysis of a female wolf also has interesting powers. (When a woman is viewed through the natural hole, she becomes the sexual slave of the viewer.) And according to Uzbak women, the head of a hoopoe is especially effective in bringing peace in a household with more than one. wife. Both men and women acquire hoopoe heads to make them popular. (The number of examples-snake bones, phallic-shaped rocks, flags, sheaves of wheat-could be multiplied indefinitely.)

\section{BIBLIOGRAPHY}

Canfield, R.L. Faction and Conversion in a Plural Society: Alignments in the Hindu Kush, Anthropological Papers, No. 50, Museum of Anthropology, University of Michigan, Ann Arbor, 1973.

Coon, C.S. Caravan, Holt, 1951.

Dupree, L. Afghanistan, Princeton, 1973.

Schurmann, H. The Mongols of Afghanistan, E.J. Brill, The Hague, 1962.

Tapper, R. and N. "The_ Role of Pastoral Nomads in a Region of Northern Afghanistan," Social Science Research Council (UK), Research Project Final Report (Mimeo.), 1973.

Wulff, H.E. The Traditional Crafts of Persia, M.I.T. Press, 1966.

Zondag, C.H. "The Case of the Afghan Karakul Institute," International Deve/opment Review 16(1):19-22, 1974. 

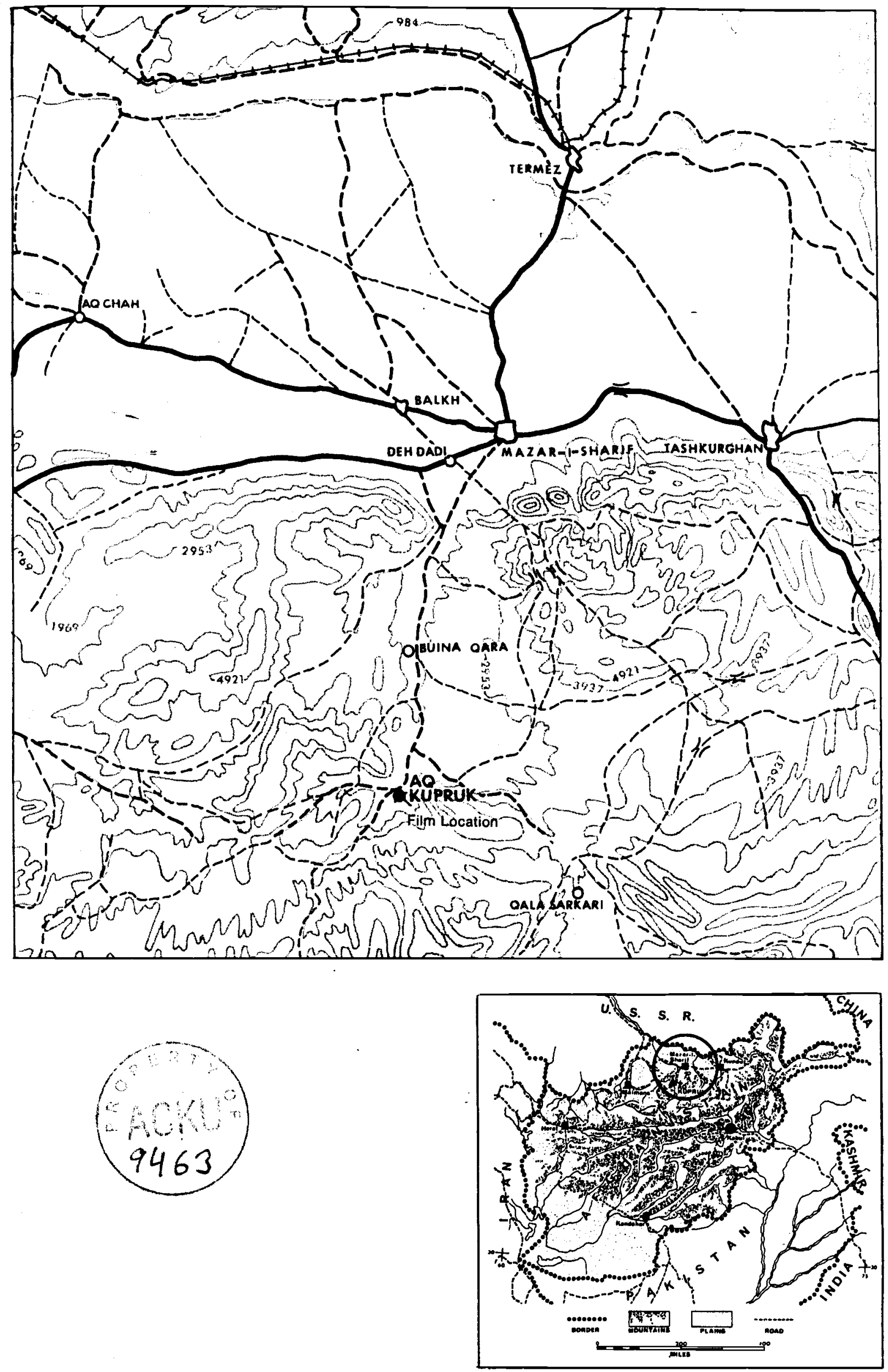